\title{
Development and Current Status of Bacillus thuringiensis for Control of Defoliating Forest Insects
}

\author{
by $\mathrm{K}$. van Frankenhuyzen ${ }^{1}$
}

\begin{abstract}
Bacillus thuringiensis $(\mathrm{Bt})$ is a naturally occurring bacterium that is now widely used for control of spruce budworm and several other defoliating forest insects in Canada. It took more than 25 years of research and development to bring Bt from first experimental use in the early 1960 s into full operational use in the mid 1980s. Critical to this process was the adoption of HD-1 for commercial use, the standardization of formulations based on international units, and the development of higher potency products. An increase in product potency from $4 \mathrm{BIU} / \mathrm{L}$ in the early 1970 s to $16.9 \mathrm{BIU} / \mathrm{L}$ in the mid $1980 \mathrm{~s}$, concomittant with improvements in formulation and application technology, reduced treatment costs while at the same time improving reliability of efficacy. A shift in political climate pushed Bt into operational use by 1985 . Since then, Bt has been used in more than half of all spruce budworm control programs. The use of highpotency formulations (12.7 to $16.9 \mathrm{BIU} / \mathrm{L})$ applied undiluted at $30 \mathrm{BIU}$ in $2.4 \mathrm{~L} /$ ha or less has significantly reduced but not eliminated initial constraints of high treatment costs and inconsistent efficacy. Current research is focussed on further reducing these constraints. In the short term, registration of formulations containing $25 \mathrm{BIU} / \mathrm{L}$ or more is expected to permit application of reduced dosages in less than $1 \mathrm{~L} / \mathrm{ha}$ and to clear the way for adoption of a split application scheme to increase reliability of efficacy. Selection and commercialization of more effective strains and the enhancement of natural strains by genetic or genetic engineering techniques offer exciting prospects for improvements in the longer term.
\end{abstract}

\section{Résumé}

Bacillus thuringiensis (B.t.) est une bactérie naturelle, aujourd'hui largement utilisée contre la tordeuse des bourgeons de l'épinette et plusieurs autres défoliateurs des forêts du Canada. Depuis son premier emploi expérimental, au début des années 60 , jusqu'a son utilisation en grand, dans le milieu des années 80 , il s'est passé plus de 25 années de recherche-développement. Une étape critique de cette évolution a été l'adoption du HD-1 pour emploi industriel, la normalisation des préparations grâce à l'emploi des unités internationales ainsi que la mise au point de produits plus puissants. Ainsi, l'accroissement de la puissance, de 4 unités biologiques internationales au litre (UBI/L), au début des années 70 , à 16,9 , au milieu des années 80 , en même temps que les améliorations des techniques de préparation et d'application, ont permis de réduire les coûts du traitement tout en améliorant la fiabilité de l'efficacité. Un nouveau climat politique a favorisé l'emploi en grand de B.t. dès 1985 . Depuis, B.t. a servi dans plus de la moitié de tous les programmes antitordeuse. Le recours à des préparations très puissantes (de 12,7 à 16,9 UBI/L) appliquées sans dilution à raison de $2,4 \mathrm{~L} /$ ha a permis de réduire considérablement, sans les éliminer complètement, les contraintes initiales posées par les coûts élevés du traitement et l'efficacité inconstante. La recherche actuelle se propose de réduire ces contraintes. À court terme, l'homologation des préparations renfermant $25 \mathrm{UBI} / \mathrm{L}$ ou plus est prévue afin de permettre l'application de doses réduites à raison de moins de $1 \mathrm{~L} / \mathrm{ha}$ et de préparer la voie à un plan d'application répétée, pour une efficacité plus fiable. La sélection et la commercialisation de souches plus efficaces ainsi que l'amélioration des souches naturelles par des techniques génétiques ou du génie génétique recèlent des promesses excitantes d'amélioration à la longue.

\section{Introduction}

The past decade of large-scale spraying against defoliating forest Lepidoptera in Canada is characterized by a gradual increase in the use of microbial insecticides based on the bacterium Bacillus thuringiensis Berliner (commonly abbreviated as $\mathrm{Bt}$ ). Aerial application of $\mathrm{Bt}$ is now considered a viable and effective strategy for providing foliage protection. It took more than 25 years of concerted collaboration between researchers, forest managers, and industry in both Canada and the United States to reduce the major obstacles of inconsistent efficacy and high cost. Many field tests were conducted between initial availability of commercial products in the early 1960s and operational acceptance in the mid 1980s. Most of those tests have been reviewed extensively (Morris et al. 1975; Smirnoff and Morris 1982; Morris 1982b; Cunningham 1985). This review describes events that made a critical contribution to the operational use of $\mathrm{Bt}$ in forestry, with emphasis on achievements in the last eight years. An overview of its current status (1989) is presented and prospects for further optimization are discussed.

\footnotetext{
${ }^{1}$ Forestry Canada, Forest Pest Management Institute, P.O. Box 490, Sault Ste. Marie, Ontario P6A 5M7.
}

\section{Background}

Bacillus thuringiensis is a naturally occurring bacterium that is pathogenic to larvae of many insect species. It was first recognized as a disease agent in silkworm in Japan and flour moths in Germany (Berliner 1915) and has since then been isolated from various species around the world (Krieg and Langenbruch 1981), including many forest insects (Morris 1982b). It now appears to be a worldwide and ubiquitous component of soil microbiota (DeLucca et al. 1981; Martin and Travers 1989).

Insecticidal activity of the bacterium is mainly associated with a parasporal protein body, often referred to as the crystal, which is formed during sporulation. After ingestion by a susceptible insect, the crystal is converted by digestive juices to a toxic protein that destroys the cells lining the gut (Percy and Fast 1983). The larva stops feeding and dies within a few days if a lethal dose is ingested, but recovers and resumes feeding if the dose is sublethal (Fast and Regniere 1984; Retnakaran et al. 1983; van Frankenhuyzen and Nystrom 1987). Germination of ingested spores and subsequent septicemia by multiplication of vegetative cells contribute to larval death in many species (Heimpel and Agnus 1959; Smirnoff 1974).

Bacillus thuringiensis is a collective name for a complex of more than 30 currently known subspecies, each with 
unique insecticidal properties (Dulmage 1981). Toxicity is exhibited specifically against Lepidoptera (e.g. subsp. kurstaki), Diptera (e.g. subsp. israelensis), or Coleoptera (e.g. subsp. tenebrionis). There is a high level of specificity within each subspecies. For example, only 200 species of predominantly foliage-feeding Lepidoptera are known to be susceptible to the kurstaki subsp., which is used in commercial formulations available for defoliator control. Because most other insect orders are unaffected (Krieg and Langenbruch 1981), Bt is a narrowspectrum insecticide that is safe to natural enemies and other beneficial and nontarget organisms (Morris 1982b).

Commercial production is achieved by fermentation (Dulmage and Rhodes 1971). When cultured in an appropriate nutrient broth, vegetative cells sporulate and eventually lyse, releasing spores and crystals into the medium. The spore-crystal complex forms the active ingredient of commercial formulations. Bt was first available commercially in the late 1930s as a product called Sporeine in France. Commercial production in North America did not begin until the early 1950s (Hall 1963) and was primarily directed against agricultural pests.

\section{Early Use}

The first experimental aerial applications of Bt in forestry were conducted in 1960 against spruce budworm, Choristoneura fumiferana, in New Brunswick (Mott et al. 1961) and black headed budworm, Acleris gloverana, in British Columbia (Kingshorn et al. 1961). Further tests in 1962 and 1969 yielded results that were encouraging but far from adequate (Morris et al. 1975). Two events in the 1960s were of particular significance to the development of Bt. First was the discovery of HD-1 (Dulmage 1970), a kurstaki isolate that was more toxic to lepidopterans than the one that was initially used in commercial products. HD-1 was quickly adopted in North America for commercial production. Second was the establishment of an international system for standardizing the potency of formulations. Early formulations were standardized on the basis of spore counts, which did not relate directly to insecticidal activity. Suggestions by Bonnefoi et al. (1958) and Burgerjon (1959) to express potency in biological units based on insect bioassays resulted in the adoption of a European Bt standard in 1966 (Burgess 1967), which was later replaced by HD-1 as the North American standard (Dulmage et al. 1971). Insecticidal activity is now routinely expressed as the number of international units per unit weight or volume, as determined in bioassays against the cabbage looper, Trichoplusia ni, in parallel with the HD-1 standard.

Availability of formulations based on HD-1 and with standardized potency started a period of intensive field testing between 1971 and 1973 in Ontario and Quebec. Formulations containing about 4 billion international units per liter (BIU/L) were tested at $10-20 \mathrm{BIU} / \mathrm{ha}$ in $4.7-18.9 \mathrm{~L}$. Although results were highly inconsistent, the good showing in some trials encouraged the expectation that Bt could indeed provide adequate foliage protection and provided the basis for continued and intensified testing in the remainder of the decade (Morris et al. 1975).

\section{Potential and Constraints}

Variable results of trials in the early 1970s (Smirnoff and Morris 1982; Morris 1982b; Dorais 1985) were attributed to inconsistent spray deposition, and consequently efforts were primarily directed at increasing the delivery of droplets to the target by improving both formulation and application technology. Formulations were altered to improve spray deposition by using spray additives (Morris et al. 1980) and to improve effectiveness by adding small amounts of the enzyme chitinase (Smirnoff et al. 1973; Smirnoff 1974; Morris 1976) or low concentrations of chemical insecticides (Morris and Armstrong 1974; Morris 1977). Various aircraft and delivery systems were tested, ranging from helicopters and single-engine biplanes equipped with rotary atomizers to four-engine aircraft fitted with boom and nozzles (Smirnoff and Morris 1982). Although effectiveness of $\mathrm{Bt}$ showed marked improvement during those trials, results remained inconsistent with cost of treatment up to four times higher than chemical insecticide treatment (Blais 1976).

Improvements in cost effectiveness were achieved in the late 1970 s when commercial formulations became more concentrated, that is, when potencies increased from 4.2 BIU/L in early products (e.g. Thuricide $16 \mathrm{~B}$ ) to $8.4 \mathrm{BIU} / \mathrm{L}$ (e.g. Thuricide 32LV, Dipel 88, Novabac 3) (Table 1). More concentrated products reduced shipping costs (bulk transport), permitted application of lower volumes, and improved spray plane productivity (Dorais 1985). By the end of the decade, performance of $\mathrm{Bt}$ for spruce budworm control had improved to the point that it was recommended for use in environmentally sensitive areas (Canada-US guidelines, Morris 1980), and was considered an operational alternative to chemical insecticides in Quebec (Dorais 1985). As a result, Bt was used operationally on about 100,000 ha in 1979 and 1980 (Table 2). However, variable efficacy and a three- to fourfold higher cost of treatment (Table 3) remained major obstacles to wider acceptance. Other constraints that put severe restrictions on spray program managers and undermined their confidence in Bt included reportedly reduced efficacy against populations exceeding 25 larvae per $45-\mathrm{cm}$ branch and a window of application that was restricted to about 10 days after onset of bud flush (Dorais 1985).

\section{Reducing the Constraints}

Use of Bt in forestry accelerated rapidly in the early 1980s. By 1985, Bt had become a fully operational insecticide that was widely used for control of spruce budworm (Table 2) as well as other defoliators (Table 4). This surge in progress can be attributed to a confluence of several critical developments. The use of higher dosages and lower volumes, operational use before cost parity was achieved, better formulations, new knowledge on effective droplet sizes and dosage requirements, and corresponding improvements in application technology all contributed to reducing the obstacles of inconsistent efficacy and high costs, while a concurrent shift in political climate favouring the use of biologicals pushed $\mathrm{Bt}$ into operational use before uncertainties were completely resolved.

\section{Application Rate}

Inconsistent efficacy arose partially from the use of marginal dosages and from the difficulty of obtaining adequate spray coverage. The dosage of $20 \mathrm{BIU}$ in $4.7 \mathrm{~L} / \mathrm{ha}$, recommended in the 1978 Canada-US guidelines (Morris 1980), was essentially a compromise between available product potency, the minimum emitted volume considered 
Table 1. Bt products currently registered or pending registration ${ }^{1}$ for aerial application in forestry.

\begin{tabular}{|c|c|c|c|c|}
\hline Year & Trade name & $\begin{array}{c}\text { Type of }{ }^{2} \\
\text { formulation }\end{array}$ & $\begin{array}{l}\text { Potency } \\
\text { (BIU/L) }{ }^{3}\end{array}$ & $\begin{array}{l}\begin{array}{l}\text { Registrant } \\
\text { (supplier) }\end{array} \\
\end{array}$ \\
\hline 1973 & Thuricide 16B & $\mathrm{FC}$ & 4.2 & Zoecon \\
\hline 1978 & Novabac-3 & FC & 8.6 & Biochem \\
\hline 1980 & Dipel 88 & $\mathrm{~S}$ & 8.4 & Abbott \\
\hline \multirow[t]{2}{*}{1981} & Thuricide 32B & $\mathrm{FC}$ & 8.4 & Sandoz \\
\hline & Thuricide $32 \mathrm{LV}$ & $\mathrm{FC}$ & 8.4 & Sandoz \\
\hline \multirow[t]{5}{*}{1984} & Thuricide $32 \mathrm{~F}$ & FC & 8.3 & Sandoz \\
\hline & Bactospeine & FC & 9.7 & Duphar \\
\hline & Futura & FC & 14.4 & Duphar (Chemagro) \\
\hline & Thuricide $48 \mathrm{LV}$ & $\mathrm{FC}$ & 12.7 & Sandoz \\
\hline & Dipel 132 & S & 12.7 & Abbott \\
\hline 1985 & Envirobac-ES & $\mathrm{FC}$ & 8.4 & Pfizer \\
\hline \multirow[t]{2}{*}{1988} & Dipel $176(8 \mathrm{~L})$ & $\mathrm{S}$ & 16.9 & Abbott \\
\hline & Futura XLV & FC & 14.8 & Duphar (Chemagro) \\
\hline \multirow[t]{2}{*}{1989} & Dipel 48AF & FC & 12.7 & Abbott \\
\hline & & $\mathrm{FC}$ & 16.9 & Abbott \\
\hline \multirow{7}{*}{1990} & Foray $48 \mathrm{~B}$ & FC & 12.7 & Novo \\
\hline & & $\mathrm{s}$ & 25.9 & Abbott \\
\hline & Futura XLV-HP & $\mathrm{FC}$ & 33.0 & Duphar (Chemagro) \\
\hline & Biodart & FC & 16.9 & ICI-Canada \\
\hline & Dipel 64AF & & & \\
\hline & Dipel 264 & & & \\
\hline & Condor & $\mathrm{FC}, \mathrm{S}$ & $\mathrm{NA}^{4}$ & Ecogen \\
\hline
\end{tabular}

${ }^{1}$ Pending registration.

${ }^{2}$ Flowable concentrate (FC); emulsifiable suspension (S).

${ }^{3}$ Billion International Units per litre (BIU/L).

${ }^{4}$ Expressed as concentration of toxin protein.

Source: Agriculture Canada, Pesticides Directorate, Ottawa.

Table 2. Operational use of $\mathrm{Bt}$ for control of spruce budworm, Choristoneura fumiferana, 1979-1988: number of hectares sprayed (ha) with $\mathrm{Bt}$ and percentage of total area treated $(\%)$.

\begin{tabular}{|c|c|c|c|c|c|c|c|c|c|c|c|c|}
\hline \multirow[b]{2}{*}{ Year } & \multicolumn{2}{|c|}{ Ontario } & \multicolumn{2}{|c|}{ Quebec } & \multicolumn{2}{|c|}{ New Brunswick } & \multicolumn{2}{|c|}{ Newfoundland } & \multicolumn{2}{|c|}{ Nova Scotia } & \multicolumn{2}{|c|}{ Total } \\
\hline & ha & $\%$ & ha & $\%$ & ha & $\%$ & ha & $\%$ & ha & $\%$ & ha & $\%$ \\
\hline 1979 & 3,454 & 17 & 17,030 & 3 & 205 & 1 & 5,870 & 100 & 556 & 100 & 27,115 & 1 \\
\hline 1980 & 4,374 & 44 & 22,180 & 12 & 10,500 & 1 & 11,761 & 100 & 25,670 & 100 & 74,485 & 4 \\
\hline 1981 & 6,576 & 67 & 15,001 & 2 & 0 & 0 & 1,900 & 1 & 31,194 & 100 & 54,671 & 2 \\
\hline 1982 & 3,068 & 90 & 31,877 & 2 & 4,000 & 1 & 4,725 & 10 & 19,153 & 100 & 62,823 & 2 \\
\hline 1983 & 2,763 & 87 & 45,627 & 4 & 10,300 & 1 & 0 & 0 & 20,726 & 100 & 79,416 & 3 \\
\hline 1984 & 2,688 & 82 & 296,568 & 42 & 37,300 & 4 & 3,110 & 12 & 20,537 & 100 & 360,660 & 20 \\
\hline 1985 & 29,370 & 100 & 512,155 & 73 & 81,000 & 12 & 3,450 & 100 & 49,719 & 100 & 675,363 & 45 \\
\hline 1986 & 150,663 & 100 & 32,789 & 50 & 111,500 & 22 & 0 & 0 & 56,155 & 100 & 351,107 & 45 \\
\hline 1987 & 76,689 & 100 & 197,992 & 100 & 91,300 & 19 & 0 & 0 & 31,080 & 100 & 397,191 & 51 \\
\hline 1988 & 14,023 & 100 & 208,064 & 100 & 210,500 & 49 & 0 & 0 & 0 & 0 & 432,587 & 63 \\
\hline 1989 & 30,516 & 100 & 165,034 & 100 & 104,900 & 18 & 0 & 0 & 0 & 0 & 300,450 & 39 \\
\hline Total & 324,184 & & $1,544,317$ & & 661,505 & & 30,816 & & 254,790 & & $2,815,612$ & \\
\hline
\end{tabular}

Sources: Carrow (1983), Annual Forest Pest Control Forum Reports, Canadian Forestry Service, Ottawa.

Table 3. Relative $\operatorname{cost}^{1}$ of treatment with Bt and chemical insecticides in New Brunswick and Quebec, 1980-1988.

\begin{tabular}{lccccccc}
\hline & \multicolumn{3}{c}{ Quebec } & & \multicolumn{3}{c}{ New Brunswick $^{2}$} \\
\cline { 2 - 4 } \cline { 6 - 7 } Year & Bt & Chem. & Ratio & & Bt & Chem. & Ratio \\
\hline 1980 & 31.31 & 8.59 & 3.6 & & & \\
1981 & 27.94 & 6.24 & 4.5 & & & \\
1982 & 18.16 & 5.79 & 3.1 & & & \\
1983 & 23.54 & 7.67 & 3.0 & & & \\
1984 & 18.63 & 10.16 & 1.8 & & 16.38 & 11.52 & 1.4 \\
1985 & 22.52 & 12.99 & 1.7 & & 18.71 & 11.82 & 1.6 \\
1986 & 17.37 & & & 16.60 & 11.50 & 1.4 \\
1987 & 23.24 & & & 21.54 & 16.42 & 1.3 \\
1988 & 23.02 & & & 21.30 & 16.98 & 1.2 \\
\hline
\end{tabular}

${ }^{1}$ Cost of operation excluding assessment and surveys, administrative overhead and research costs in \$/ha.

${ }^{2}$ Small spray planes only, not including TBM.

Source: N. Carter, NB Dept. Natural Resources; L. Dorais, Quebec Department of Energy and Resources. necessary to obtain adequate coverage, and the desire to reduce treatment costs. Most of the experimentation throughout the 1970s was conducted within the recommended rate of $20 \mathrm{BIU} / \mathrm{ha}$, even though the minimum effective dosage rate had never been determined. Inadequacy of this application rate was first suspected when Fast (1976) compared expected dose on the target foliage with estimated dose requirements for spruce budworm larvae, and was confirmed between 1979 and 1981 when the guidelines were tested in extensive field trials under the auspices of CANUSA (Morris 1980, 1981; Cunningham 1985). It was not until 1981 and 1982 that field tests were designed specifically to determine optimum dosage and volume application rates (Morris 1984; Lewis et al. 1984). The general conclusion was that $20 \mathrm{BIU} /$ ha was effective only under optimum conditions and against low populations, whereas $30 \mathrm{BIU} /$ ha produced much more consistent results, even against populations exceeding 30 larvae per 45-cm branch (Morris 1982a; Carrow 1983; Dorais 1985). 
Table 4. Operational use of Bt against defoliating forest insects, 1985-1989.

\begin{tabular}{|c|c|c|c|c|c|c|}
\hline \multirow[b]{2}{*}{ Target species } & \multicolumn{5}{|c|}{ Number of hectares sprayed in: } & \multirow[b]{2}{*}{ Total } \\
\hline & 1985 & 1986 & 1987 & 1988 & 1989 & \\
\hline Spruce budworm & 675,694 & 351,107 & 397,061 & 432,587 & 304,948 & $2,161,196$ \\
\hline Jack pine budworm & 248,676 & 482,032 & 105,463 & 0 & 4,763 & 840,934 \\
\hline Hemlock looper & 2,365 & 5,420 & 4,183 & 23,788 & 5,362 & 41,118 \\
\hline Gypsy moth & 170 & 103,094 & 40,249 & 13,784 & 12,951 & 170,248 \\
\hline Total & 926,905 & 941,653 & 546,956 & 470,159 & 328,024 & $3,213,496$ \\
\hline
\end{tabular}

Source: Annual Forest Pest Control Forum Reports, Forestry Canada, Ottawa.

Availability of concentrated formulations permitted application of the higher dosage in a lower volume. The initial call for concentrated products was based on the desire to reduce shipping costs and volume application rates (Blais 1976). Pioneering work in this area was done by Smirnoff, who developed a concentrated formulation (Futura) that could be applied at $20 \mathrm{BIU} / \mathrm{ha}$ in a final volume of $2.5 \mathrm{~L}$. Trials at that rate were conducted as early as 1978 (Smirnoff 1980). Consistently good results between 1980 and 1983 (Smirnoff and Valero 1983; Smirnoff 1985) resulted in the registration of Futura in 1984 (Table 1). Commercial formulations containing $12.7 \mathrm{BIU} / \mathrm{L}$ became available for experimental use in the early 1980s. Application of such formulations at $30 \mathrm{BIU} / \mathrm{ha}$ in $2.4 \mathrm{~L}$ provided excellent results (Dimond 1982) and was as effective as application in 4.7 or $9.4 \mathrm{~L} / \mathrm{ha}$ (Morris 1984). These findings were reflected in updated guidelines for operational use (Morris et al. 1984; Dimond and Morris 1984).

\section{Operational Experience}

Operational use before cost and efficacy were competitive with chemical insecticides catalysed significant cost reductions and provided the experience needed to improve efficacy. From 1979 to 1983 , Bt was applied as a small but consistent proportion of the spruce budworm control program (Table 2) at 20-30 BIU in 2.4-7.0 L/ha (Carrow 1983). Increased use and competitive bidding by suppliers forced the price down. The average cost per BIU dropped from $\$ 0.68$ in 1980 to $\$ 0.32$ in 1983 and the costs per hectare fell from $\$ 13.18$ to $\$ 6.96$ in spite of a general increase in dosage from 20 to $30 \mathrm{BIU} /$ ha (Carrow 1983). By 1983 the differential in application costs between Bt and chemical insecticides had narrowed to a two- to three-fold difference, depending on the jurisdiction. Practical experience gained from operational use between 1979 and 1983 also reduced the problem of reliability; users agreed that foliage protection at $30 \mathrm{BIU} / \mathrm{ha}$ was generally as good as that obtained with chemical insecticides (Carrow 1983). Early operational experience thus precipitated essential cost reductions while increasing confidence in the product, which opened the door for much wider use in subsequent years.

\section{Undiluted Application}

The trend of the late 1970s to increase product potency continued in the 1980s. Initial problems with handling of the highly viscous formulations were eliminated with the introduction of low-viscosity formulations. Potency of registered products increased from $8.4 \mathrm{BIU} / \mathrm{L}$ in 1980 to $12.7 \mathrm{BIU} / \mathrm{L}$ in 1984 and $16.9 \mathrm{BIU} / \mathrm{L}$ in 1988 (Table 1). The major benefit of the high-potency formulations was that they could be applied undiluted because they were designed for optimum atomization and reduced droplet evaporation. Application of undiluted formulations had yielded promising results in trials in 1981 and 1982 (Dimond 1982; Morris 1984) and was increasingly seen as the ultimate way to reduce treatment costs (Carrow 1983; Dimond and Morris 1984). Application of undiluted product was first used operationally in 1982 in New Brunswick on 3,200 ha (Kettela 1983, 1985), and became the standard for spruce budworm control after 1984, when formulations containing $12.7 \mathrm{BIU} / \mathrm{L}$ were approved for operational use. From then on, Bt was routinely applied at 20 or $30 \mathrm{BIU} / \mathrm{ha}$ in 1.6 or $2.4 \mathrm{~L}$. Successful application of such low volumes hinged on concurrent improvements in application technology that were based on a better understanding of effective droplet sizes and dose requirements (see next section).

Application of undiluted high-potency products undoubtedly made the most important contribution to reducing the constraints of high cost and unreliable efficacy. The use of low spray volumes reduced application costs by increasing spray plane productivity. Elimination of on-site mixing further increased plane productivity by allowing more loads per spray period. For example, productivity of four-engine sprayplanes in the Quebec spray program increased from 42,740 ha per year for application of $20 \mathrm{BIU}$ in $4.7 \mathrm{~L} / \mathrm{ha}$ (diluted) to 125,320 ha for undiluted application of the same dose in $1.6 \mathrm{~L} / \mathrm{ha}$ (Dorais 1985). Furthermore, handling time and costs were reduced and problems associated with instability of mixed formulations were avoided, thus facilitating overall program management. The net effect of those factors was a further narrowing of the cost differential between $\mathrm{Bt}$ and chemicals (Table 3). In the state of Maine, total treatment cost showed a three-fold reduction between 1980 and 1985 (Irland and Rumpf 1987). The use of high-potency products also increased efficacy and reliability. In the 1984-1986 spray programs in Quebec, when both chemical insecticides and Bt were used on a large scale, single applications of Bt at $30 \mathrm{BIU} / \mathrm{ha}$ in $2.4 \mathrm{~L}$ performed generally as well as double applications of chemicals (Table 5). However, this was not the case in New Brunswick in 1988 (Carter 1988).

\section{Effective Droplet Size and Dose Requirements}

Implementation of undiluted application depended critically on improvements in the application of chemical insecticides, in particular the use of small droplets. In early Bt applications, spray systems were calibrated to deliver droplets in the 100-300 $\mu \mathrm{m}$ size range in an effort to optimize spray deposition as measured on Kromekote cards (Morris 1980; Morris et al. 1984). Data generated by the New Brunswick Spray Efficacy Research Group in the early 1980s (Picot et al. 1985, 1986) and work on the pine beauty moth, 
Table 5. Comparative efficacy of Bt and chemical insecticides for operational control of spruce budworm in Quebec, 1984-1986.

\begin{tabular}{|c|c|c|c|c|c|c|c|}
\hline Year & Product & Dosage/ha & $\begin{array}{c}\text { Volume } \\
\text { (L/ha }\end{array}$ & $\begin{array}{l}\text { Total } \\
\text { area } \\
\text { (ha) }\end{array}$ & $\begin{array}{c}\text { No. } \\
\text { larvae } \\
\text { /45-cm tip }\end{array}$ & $\begin{array}{c}\% \\
\text { Mortality }\end{array}$ & $\begin{array}{c}\% \\
\begin{array}{c}\text { Reduction } \\
\text { in } \\
\text { defoliation }\end{array}\end{array}$ \\
\hline 1984 & $\begin{array}{l}\text { Matacil } \\
\text { Thu 48LV }\end{array}$ & $\begin{array}{l}2 \times 52 \mathrm{~g} \mathrm{ai}^{1} \\
1 \times 30 \mathrm{BIU}^{2}\end{array}$ & $\begin{array}{l}1.4 \\
2.4\end{array}$ & $\begin{array}{l}141,521 \\
182,346\end{array}$ & $\begin{array}{l}7.4 \\
7.4\end{array}$ & $\begin{array}{l}77.0 \\
73.0\end{array}$ & $\begin{array}{l}43 \\
35\end{array}$ \\
\hline 1985 & $\begin{array}{l}\text { Fenitro } \\
\text { Thu } 48 \mathrm{LV}\end{array}$ & $\begin{array}{l}2 \times 210 \mathrm{~g} \text { ai } \\
1 \times 30 \mathrm{BIU}\end{array}$ & $\begin{array}{l}1.4 \\
2.4\end{array}$ & $\begin{array}{l}162,676 \\
456,639\end{array}$ & $\begin{array}{l}8.0 \\
8.8\end{array}$ & $\begin{array}{l}81.2 \\
83.0\end{array}$ & $\begin{array}{l}40 \\
46\end{array}$ \\
\hline 1986 & $\begin{array}{l}\text { Fenitro } \\
\text { Thu 48LV }\end{array}$ & $\begin{array}{l}2 \times 210 \mathrm{~g} \text { ai } \\
1 \times 30 \mathrm{BIU}\end{array}$ & $\begin{array}{l}1.4 \\
2.4\end{array}$ & $\begin{array}{l}33,038 \\
18,160\end{array}$ & $\begin{array}{l}13.8 \\
14.4\end{array}$ & $\begin{array}{l}93.5 \\
86.1\end{array}$ & $\begin{array}{l}33 \\
31\end{array}$ \\
\hline
\end{tabular}

${ }^{1}$ Grams active ingredient ( $\mathrm{g}$ ai).

${ }^{2}$ Billion International Units (BIU).

Source: L. Dorais, M. Auger, Quebec Dept. of Energy and Resources.

Panolis flammea, in Scotland (Holden and Bevan 1978) provided overwhelming evidence that droplets of $<100 \mu \mathrm{m}$ impinge more effectively on coniferous foliage than large droplets. The use of such small droplets requires efficient atomization of the spray formulation. For aerial application this is best achieved with rotary atomizers. Availability of non-volatile, low-viscosity formulations permitted direct translation of this concept to the application of Bt. Rotary atomizers are capable of generating a high proportion of droplets below $100 \mu \mathrm{m}$ from small volumes of undiluted high-potency formultations (Yates and Cowden 1986) and are the key to success of undiluted applications.

Because Bt has to be ingested to be effective, success of a spray treatment is determined by the interaction between insect feeding activity, the number of spray droplets per unit feeding area and the dose in those droplets. The importance of droplet density has long been recognized. Spray volumes were chosen and aircraft were calibrated to obtain a deposit of at least 25 droplets per square centimeter on Kromekote cards placed on the ground (Smirnoff and Morris 1982; Morris 1980) because lower deposits were associated with poor efficacy (Grimble and Morris 1983). The dose delivered to the target foliage was not assessed as a critical determinant of efficacy until 1981 when Fast and Sundaram (unpublished data) explored the interaction between size, density and toxicant concentration of spray droplets in determining spruce budworm mortality. Using a droplet size of 30-50 $\mu \mathrm{m}$, they demonstrated that increasing product concentration from 2.1 to $12.7 \mathrm{BIU} / \mathrm{L}$ increased mortality from 20 to $>90 \%$. The number of droplets required to obtain $50 \%$ mortality decreased from 10 droplets per needle for a 2.1 BIU/L concentration to $<1$ droplet for $8.4 \mathrm{BIU} / \mathrm{L}$. In a subsequent field trial in 1983, a deposit of 1 droplet per needle of a $6.3 \mathrm{BIU} / \mathrm{L}$ spray mixture resulted in a 50\% reduction in larval survival (Fast et al. 1985a). Work in Quebec in 1984 established that 0.5 droplets per needle of a $12.7 \mathrm{BIU} / \mathrm{L}$ formulation was required to obtain $50 \%$ foliage protection or more (Lambert 1987).

The pronounced effect of concentration on the density of spray droplets required for acceptable efficacy was further demonstrated in field trials in 1984 and 1985. Fast et al. (1985b, 1986) related estimates of larval survival and defoliation to density of spray droplets (mostly in the 25-75 $\mu \mathrm{m}$ size range) on balsam fir foliage for formulations containing 8.4-16.9 $\mathrm{BIU} / \mathrm{L}$ after undiluted application at $30 \mathrm{BIU} / \mathrm{ha}$. Higher potency products provided better efficacy, particularly at lower deposits. Similar relationships were established in subsequent years for various high-potency products (e.g. Wiesner and Kettela 1987). In general, formulations with $12.7 \mathrm{BIU} / \mathrm{L}$ or more provided at least $50 \%$ reduction in defoliation at a deposit of 0.5 droplets per needle, while higher droplet densities were required for less concentrated formulations. A high concentration of $\mathrm{Bt}$ in the spray droplets thus played a key role in the increase in efficacy associated with undiluted application.

\section{Volume versus Concentration}

Work by Fast $e$ t al. $(1985,1986)$ was significant because it demonstrated the dominant role of product potency in determining efficacy. Their findings suggest that the more concentrated the formulation is, the fewer droplets are required to deliver an efficacious dose to the target and the more consistent efficacy will be. Thus, optimum dosage requirements should be considered in terms of BIU/L rather than BIU/ha. If the potency is high enough, acceptable efficacy should be obtainable at lower application rates as long as the applied volume can be atomized into a sufficient number of droplets to deliver an efficacious dose to the target. That thinking stimulated the development of products with even higher potencies, currently up to $33.0 \mathrm{BIU} / \mathrm{L}$ (Table 1), which can be applied in volumes as low as 0.6 or $0.9 \mathrm{~L} / \mathrm{ha}$, and provided the basis for the development of the so-called enhanced atomization application technique.

\section{Enhanced Atomization Application}

Droplets 15-55 $\mu \mathrm{m}$ in diameter appear optimal for spruce budworm-insecticide contact on coniferous foliage (Picot et al. 1985, 1986). They also impinge effectively on silk strands of budworm feeding shelters, which may be an important dose transfer mechanism (Nigam 1987). Droplet volume in that size range generated by rotary atomizers can be enhanced by reducing the flow rate. Van Vliet and Picot (1987) demonstrated in wind tunnel studies that the Micronair AU4000 atomizer produced $>80 \%$ of the emitted volume in the 15-55 $\mu \mathrm{m}$ size range at flow rates below $2 \mathrm{~L} / \mathrm{min}$. Such flow rates allow maximum rotational speed and enhance atomization of the spray liquid compared with the standard flow rates of 5-7 L/min, thus producing more droplets in the effective size range. Enhanced atomization trials in New Brunswick in 1987 demonstrated that undiluted application of a $12.7 \mathrm{BIU} / \mathrm{L}$ formulation at $15 \mathrm{BIU} / \mathrm{ha}$ using a flow rate of $2 \mathrm{~L} / \mathrm{min}$ per atomizer was as effective against spruce 




Figure 1. Use of various $\mathrm{Bt}$ formulations in operational spraying against forest defoliators in all jurisdictions, 1985-1988.

budworm as the standard application of $30 \mathrm{BIU} / \mathrm{ha}$ using $6.7 \mathrm{~L} / \mathrm{min}$. Availability of products containing $33 \mathrm{BIU} / \mathrm{L}$ in 1988 enabled application of $15 \mathrm{BIU} / \mathrm{ha}$ in $0.5 \mathrm{~L}$. Droplet deposition and efficacy were comparable with conventional application of $30 \mathrm{BIU} / \mathrm{ha}$ using $5.0 \mathrm{~L} / \mathrm{min}$ (E. G. Kettela, unpublished data). Work is continuing to further test this promising technique.

\section{Operational Use}

The proportion of the area treated with Bt increased from $1-4 \%$ between 1979 and 1983 to $20 \%$ in 1984 and $45-50 \%$ in subsequent years (Table 2). This was primarily due to increasing use in Quebec, and in Ontario following the provincial government's decisions in 1985 to stop aerial use of chemical insecticides in public forests. Chemical insecticides remained the main tool in New Brunswick until 1988 when Bt was used in almost half of the program. Although increasing public pressure against the use of chemical insecticides in forests played a key role in the switch to $\mathrm{Bt}$, the switch was possible because improvements in efficacy and cost effectiveness achieved in the early 1980s gave politicians a viable, albeit more expensive, alternative.

Operational use after 1984 involved predominantly undiluted applications of formulations with 12.7 or 14.4 $\mathrm{BIU} / \mathrm{L}$ at 20 or $30 \mathrm{BIU}$ in $1.6-2.4 \mathrm{~L} / \mathrm{ha}$. The main products used were Dipel 132, Thuricide 48LV, and Futura (Fig. 1.). First operational use of a $16.9 \mathrm{BIU} / \mathrm{L}$ product (Dipel 176) at $30 \mathrm{BIU}$ in $1.8 \mathrm{~L} / \mathrm{ha}$ occurred in 1988 in Newfoundland against hemlock looper, Lambdina fiscellaria fiscellaria. Formulations containing 25-33 BIU/L have been available for experimental use since 1986 and were successfully tested in volumes of $0.9-1.2 \mathrm{~L} /$ ha against spruce budworm (Wiesner and Kettela 1987; Kettela, unpublished data), and hemlock looper (West et al. 1989). Super-high potency formulations thus allow application volumes that are comparable with or below those for chemical insecticides and are expected to become the mainstay of forest protection programs as soon as registrations are completed (Table 1).

With increasing restrictions on chemical insecticides in recent years, the use of $\mathrm{Bt}$ was extended to control several other defoliating species (Table 4). A recent outbreak of jack pine budworm, Choristoneura pinus pinus, in Ontario and Manitoba resulted in extensive control operations between 1985 and 1987. Because laboratory bioassays indicated a similar level of susceptibility as the spruce budworm (van Frankenhuyzen and Fast 1989), application of undiluted high-potency formulations was recommended and successfully implemeted. Formulations with $12.7 \mathrm{BIU} / \mathrm{L}$ applied at $20 \mathrm{BIU}$ in $1.6 \mathrm{~L} /$ ha generally provided satisfactory foliage protection.

Operational control of the gypsy moth, Lymantria dispar, in Ontario started in 1985 and mushroomed to 100,000 ha in 1986. High-potency formulations were diluted and applied at $30 \mathrm{BIU}$ in 5-6 L/ha because a high volume application rate was considered necessary to obtain adequate coverage of foliage throughout the hardwood canopy. However, studies in 1987 and 1988 demonstrated that application of undiluted Bt provided better canopy penetration and equivalent larval mortality at lower spray depostis than application of diluted Bt in higher volumes (van Frankenhuyzen et al. 1989). The 1988 program was consequently conducted with undiluted product applied at $30 \mathrm{BIU} / \mathrm{ha}$ in $2.4 \mathrm{~L}$ and was the most effective gypsy moth control program conducted to date (G. M. Howse, unpublished data).

Undiluted application of high-potency products was also successful in experimental programs against eastern hemlock looper in Newfoundland (West et al. 1987, 1989) and operational use increased from $2-6 \%$ in $1985-1987$ to $34 \%$ in 1988. Foliage protection was generally equivalent to that of fenitrothion (Table 6). Many other defoliators are susceptible to Bt including occasional outbreak species such as forest tent caterpillar, Malacosoma disstria, eastern tent caterpillar, M. americanum, western spruce budworm, Choristoneura occidentalis, black headed budworms, Acleris sp., and white marked tussock moth, Orgyia leucostigma. Field tests are needed to determine the feasibility of using undiluted $\mathrm{Bt}$ for control of these species.

\section{Current Constraints and Future Prospects}

After almost 30 years of research and development, Bt has become a major tool in forest protection programs. Operational use of high-potency formulations applied undiluted in low volumes has reduced but not eliminated the initial constraints of high treatment costs and inconsistent efficacy. Operational costs are still higher than for chemical insecticides (Table 3), but the main drawback is that efficacy is more dependent on proper timing of application and favorable postspray weather, which results in a narrower window of application and less predictable efficacy. The 1988 experience in New Brunswick is a good example of this: reduction in defoliation was $61 \%$ for fenitrothion compared with $24 \%$ for Bt (Table 7). Current research to reduce these constraints is focussed on developing higher potency products with greater foliar persistence, and product improvement by selection of more effective strains and by biotechnological manipulation. 
Table 6. Comparative efficacy of Bt and fenitrothion for operational control of the hemlock looper in Newfoundland, 1986-1988.

\begin{tabular}{|c|c|c|c|c|c|c|c|c|}
\hline \multirow[b]{2}{*}{ Year } & \multirow[b]{2}{*}{ Product } & \multirow[b]{2}{*}{ Dosage/ha } & \multirow{2}{*}{$\begin{array}{c}\text { Volume } \\
\text { (L/ha) }\end{array}$} & \multirow{2}{*}{$\begin{array}{c}\text { Area } \\
\text { (ha) }\end{array}$} & \multicolumn{4}{|c|}{$\%$ area with defoliation } \\
\hline & & & & & nil & light & mod. & severe \\
\hline \multirow[t]{2}{*}{$1986^{\prime}$} & Fenitro $^{2}$ & $2 \times 210 \mathrm{~g} \mathrm{ai}^{3}$ & 1.5 & 79,028 & 84 & 3 & 3 & 10 \\
\hline & Dipel 132 & $1 \times 30 \mathrm{BIU}^{4}$ & 2.4 & 5,420 & 76 & 0 & 0 & 24 \\
\hline \multirow[t]{2}{*}{$1987^{5}$} & Fenitro & $1 \times 210 \mathrm{~g}$ ai & 1.5 & 164,362 & 84 & 5 & 3 & 8 \\
\hline & Dipel 132 & $1 \times 30 \mathrm{BIU}$ & 2.4 & 4,183 & 78 & 6 & 1 & 15 \\
\hline \multirow[t]{6}{*}{1988} & Fenitro & $2 \times 210 \mathrm{~g} \mathrm{ai}$ & 1.5 & 45,138 & 91 & 6 & $<1$ & 2 \\
\hline & Dipel 176 & $1 \times 30 \mathrm{BIU}$ & 1.8 & 6,473 & 91 & 7 & $<1$ & 7 \\
\hline & Futura XLV & $1 \times 30 \mathrm{BIU}$ & 2.0 & 3,704 & 94 & 3 & $<1$ & 3 \\
\hline & Dipel 176 & $2 \times 30 \mathrm{BIU}$ & 1.8 & 1,372 & 100 & - & - & - \\
\hline & Dipel 176+ & $1 \times 30 \mathrm{BIU}$ & 1.8 & & & & & \\
\hline & +Fenitro & $1 \times 210 \mathrm{~g}$ ai & 1.5 & 10,410 & 97 & 2 & $<1$ & $<1$ \\
\hline
\end{tabular}

About $1.5 \%$ of area received single application of fenitrothion.

${ }^{2}$ Fenitrothion (Fenitro).

${ }^{3}$ Grams active ingredient ( $\mathrm{g}$ ai).

${ }^{4}$ Billion International Units (BIU).

${ }^{5}$ About $9.6 \%$ of area received double application of fenitrothion.

Source: H. Crummey, Newfoundland Dept. Forest Resources and Lands.

Table 7. Comparative efficacy of Bt and fenitrothion for operational control of the eastern spruce budworm in New Brunswick, 1988.

\begin{tabular}{llcccc}
\hline Product & Dosage/ha & $\begin{array}{c}\text { Volume } \\
(\text { L/ha) }\end{array}$ & $\begin{array}{c}\text { Area } \\
\text { (ha) }\end{array}$ & $\begin{array}{c}\text { No. Larvae } \\
\text { /45-cm tip }\end{array}$ & $\begin{array}{c}\% \\
\text { Mortality }\end{array}$ \\
\hline Fenitro' & $2 \times 210 \mathrm{~g} \mathrm{ai}^{2}$ & 1.4 & 231,000 & 21.6 & 72 \\
Futura XLV & $1 \times 30 \mathrm{BIU}^{3}$ & 2.0 & 210,500 & 26.0 & 51 \\
in \\
\hline
\end{tabular}

${ }^{1}$ Fenitrothion (Fenitro).

${ }^{2}$ Grams active ingredient (g ai).

${ }^{3}$ Billion International Units (BIU).

Source: Carter (1988).

\section{Improved Formulations}

The development of formulations with higher potency and greater residual toxicity is considered the key to short-term improvement of Bt efficacy. The benefit of such formulations is several-fold. Variable tree and insect phenology within large spray blocks make proper timing of a single spray application difficult, particularly when using Bt which has no contact toxicity and limited residual toxicity. Reliability of Bt can be increased by adopting a split application scheme, as is used for chemical insecticides, but high treatment costs have until now prohibited this. However, registration of formulations with much higher potencies in the near future is hoped to permit operational use of reduced dosages at $0.5 \mathrm{~L} / \mathrm{ha}$ (see "Enhanced atomization application"), which could reduce treatment costs to a level where split applications become competitive. Higher product potency is also expected to decrease the dependance of treatment success on favorable weather after application by ensuring rapid ingestion of a lethal dose (van Frankenhuyzen 1990). Another prerequisite to improving reliability of Bt efficacy is better persistence of spray deposits on the foliage. Residual toxicity of present formulations is limited to a few days, particularly under rainy conditions (van Frankenhuyzen and Nystrom 1989). Increased persistence of spray deposits will minimize adverse effects of postspray rain, thereby allowing more latitude in timing of spray application.

\section{Strain Selection and Modification}

An alternative approach to reducing cost and increasing effectiveness of $\mathrm{Bt}$ is the commercialization of strains with specific toxicity to forest insects. This can be achieved by identifying natural isolates with the desired activity range or by enhancing natural strains using conventional genetic techniques or genetic engineering techniques.

Of the naturally occurring strains, the HD-1 isolate of current formulations is one of literally thousands of possible candidates (Martin and Travers 1989), but efforts to identify more potent strains have yielded little benefit for forest insect control to date (Morris and Moore 1983; Dubois 1985; Dubois et al. 1989). However, new strains are continually being isolated (Travers et al. 1987) and the search for more effective ones is actively pursued. One example of possible success in forestry is commercialization of the strain A20 (Biodart, Table 1), although superior performance in the field has yet to be demonstrated.

Genetic enhancement of toxicity is an approach that was used by Ecogen to produce Condor (Table 1). Toxin genes of two strains were combined by employing a native conjugal plasmid transfer system to improve toxicity to spruce budworm and gypsy moth. Condor is currently undergoing field tests for registration. Condor is also an example of a new approach for standardization of product potency, based on quantification of toxin protein content. The proliferation 
of target-specific products is making the use of international units obsolete and cumbersome. Because activity against cabbage looper is often not meaningful, each product needs to be labelled with different international units for each target pest. Examples are the recent introduction of units for the Colorado potato beetle, Leptinotarsa decemlineata, (Zehnder and Gelernter 1989) and Spodoptera for standardization of products developed specifically against these targets.

The great diversity of natural strains, each with a different activity spectrum, offers opportunities for the application of genetic engineering techniques. Because genes that code for crystal proteins are located on plasmids, they are highly amenable to modification by using recombinant DNA techniques. Modifications include increased toxin yield, altered range of insectidal activity, or enhanced environmental persistence (Luthy 1986; Wilcox et al. 1986; Whiteley and Schnepf 1986). Biotechnological improvement of Bt is enjoying worldwide commercial interest, but most efforts are focussed on the larger agricultural market. In Canada, a research network was established in 1984 with the goal of tailoring an improved Bt product for forest insect control. The network, called Biocide, involves researchers from Forestry Canada, National Research Council, and several universities. Toxin genes from various strains were cloned and sequenced (Hefford et al. 1987) and researchers are now elucidating molecular determinants of toxin activity and specificity. Site-directed mutagenesis and chemical modification will then be used to manipulate these determinants to achieve maximum benefit for forestry applications. In addition, a mechanism of sunlight inactivation of the crystal protein has been established (Pozsgay et al. 1987) and ways of improving stability in sunlight are being explored. Achievements to date will accelerate the development of novel, targetspecific microbial insecticides based on recombinant Bt.

The future of Bt for forest insect control looks bright. Now that operational use is well established, manufacturers are increasingly confident that they face a promising market. Increasing competition (from three main producers in 1985 to seven potential contenders in 1988) is expected to accelerate product improvement and result in further cost reductions in the short term. Genetic engineering offers exciting opportunities in the long term, provided risks associated with the release of genetically-engineered microorganisms (Primentel et al. 1989) can be minimized and regulatory requirements can be worked out. After 30 years of research and development, we are just beginning to understand and exploit the real potential of $\mathrm{Bt}$ for control of forest insects.

\section{References}

Berliner, E. 1915. Uber die Schlaffsucht der Mehlmottenraupe (Ephestia Kuhniella Zell) and ihren Erreger, Bacillus thuringiensis. Z. Angew. Entomol. 2: 29-56.

Blais, J.R. 1976. Can Bacillus thuringiensis replace chemical insecticides in the control of spruce budworm? For Chron 52: 57-60.

Bonnefoi, A., A. Burgerjon and P. Grison. 1958. Titrage biologique des preparations de spores de Bacillus thuringiensis. C.R. Acad. Sci. 247: 1418-1420.

Burges, H.D. 1967. The standardization of products based on Bacillus thuringiensis. pp. 306-338 In Proc. Int. Colloq. Insect Pathol. and Microb. Control, Wageningen, the Netherlands, 1966. North Holland Publ. Co., Amsterdam.
Burges, H.D. 1981. Microbial Control of Pests and Plant Diseases 1970-1980. Academic Press, London.

Burgerjon, A. 1959. Titrage et definition d'une unite biologique pour les preparations de Bacillus thuringiensis Berliner. Entomophaga 4: 201-206.

Carrow, J.R. 1983. Bt and the spruce budworm-1983. New Brunswick Dep. Nat. Resour., Fredericton, N.B.

Carter, N. 1988. Protection spraying against spruce budworm in New Brunswick, 1988. N.B. Dep. Nat. Resour. and Energ., Fredericton, N.B.

Cunningham, J.C. 1985. Biorationals for control of spruce budworms. pp. 320-349 In Sanders et al. (Eds.), Recent advances in spruce budworms research. Proc. CANUSA Spruce Budworms Research Symposium, Bangor, Maine, Sept. 1984. Can. For. Serv., Ottawa, Ont.

DeLucca, A.J., J.G. Simonson and A.D. Larson. 1981. Bacillus thuringiensis distribution in soils of the United States. Can. J. Microbiol. 27: 865-870.

Dimond, J.B. 1982. Effects of aerial sprays of undiluted Bacillus thuringiensis formulations on spruce budworm. Maine Life Sci. Agric. Exp. Station, Univ. Maine at Orono. Misc. Rep. No. 274.

Dimond, J.B. and O.N. Morris. 1984. Microbial and other biological control. pp 104-114 In Spruce budworms handbook: Managing the spruce budworm in eastern North America. USDA For. Serv., Agriculture Handbook No. 620, Washington, D.C.

Dorais, L. 1985. Four engine aircraft experience in the application of Bacillus thuringiensis against the spruce budworm in Quebec. pp. 13-15 In Grimble, D.G., and F.B. Lewis (Eds.).

Dubois, N.R. 1985. Selection of new more potent strains of Bacillus thuringiensis for use against gypsy moth and spruce budworm. p. 99-102 In: Grimble, D.G and F.B. Lewis (Eds.). Proc. gymp. on aerral application of pesticides in forestry. Assoc. Comm. on Agric. and For. Aviation. NRC, Ottawa. AFA-TN-18, NRC No. 29197.

Dubois, N.R., P.J. Huntley, and D. Newman. 1989. Potency of Bacillus thuringiensis against gypsy moth and spruce budworm larvae: 1980-86. USDA For. Serv., Northeastern For. Exp. Sta., GTR-NE-131.

Dulmage, H.T. 1970. Insecticidal activity of HD-1, a new isolate of Bacillus thuringiensis var. alesti. J. Invert. Pathol. 15: 232-239.

Dulmage, H.T. 1981. Insecticidal activity of isolates of Bacillus thuringiensis and their potential for pest control. pp. 193-222 In Burges, H.D. (Ed.). Microbial Control of Pests and Plant Disease. Academic Press, London.

Dulmage, H.T., O.P. Boening, C.S. Rehnborg and G.D. Hansen. 1971. A proposed standardized bioassay for formulations of Bacillus thuringiensis based on the International Unit. J. Invert. Pathol. 18: 240-246.

Dulmage, H.T. and R.A Rhodes. 1971. Production of pathogens in artificiqal media. p. 507-540 In: Burges, H.D. and N.W. Hussey (Eds.), Microbial Control of Insects and Mites. Academic Press, London.

Fast, P.G. 1976. Some calculations relevant to field applications of Bacillus thuringiensis. Can. For. Serv. Bi-monthly Res. Notes. 32: 21.

Fast, P.G. and J. Regniere. 1984. Effect of exposure time to Bacillus thuringiensis on mortality and recovery of the spruce budworm (Lepidoptera: Tortricidae). Can. Ent. 116: 123-130.

Fast, P.G., E.G. Kettela and C.J. Wiesner. 1985a. Measurement of foliar deposits of $\mathrm{Bt}$ and their relation to efficacy. pp. 148-149. In D.G. Grimble and F.L. Lewis (Eds.). Proc. Symp: Microbial control of spruce budworms and gypsy moths, Windsor Locks, April 1984 USDA For. Serv. GTR-NE-100. 
Fast, P.G., E.G. Kettela and C.J. Wiesner. 1985b. Assessment of the influence of concentration and foliar deposition on the efficacy of Bacillus thuringiensis. New Brunswick Research and Productivity Council Report No. C/85/047.

Fast, P.G., E.G. Kettela and C.J. Wiesner. 1986. Assessment of efficacy of Bacillus thuringiensis against the spruce budworm. New Brunswick Research and Productivity Council Report No. C/86/005.

Green, G.W. (Ed.). 1987. Proceedings Symposium on the aerial application of pesticides in forestry. Assoc. Comm. on Agric. and For. Aviation, National Research Council, Ottawa, Ont. AFA-TN-18, NRC No. 29197.

Grimble, D.G. and F.B. Lewis. 1985. Proceedings of a Symposium: Microbial Control of Spruce Budworms and Gypsy moths, Windsor Locks, Conn., April 1984. USDA For. Serv., Broomall, Penns., GTR-NE-100.

Grimble, D.G. and O.N. Morris. 1983. Regional evaluation of $\mathrm{Bt}$ for spruce budworm control. Agric. Info. Bull. 458, USDA For. Serv., Washington, D.C.

Hall, I.M. 1963. Microbial control. pp. 477-517 In Steinhaus, E.A. (Ed.). Insect Pathology, An Advanced Treatise. Academic Press, New York.

Hefford, M., R. Brousseau, G. Prefontaine, Z. Hanna, J. Condie and P.C.K. Lau. 1987. Sequence of a Lepidopteran toxin gene of Bacillus thuringiensis subsp. kurstaki NRD-12. J. Biotech. 6: 307-322.

Heimpel, A.M. and T.A. Angus. 1959. The site of action of crystalliferous bacteria in Lepidoptera larvae. J. Insect Pathol. 1: $152-170$.

Holden, A.V. and D. Bevan. 1978. Control of pine beauty moth by fenitrothion in Scotland, 1978. For. Comm. Rep., Farnham, Surrey, England.

Irland, L.C. and T.A. Rumpf. 1987. Cost trends for Bacillus thuringiensis in the Maine spruce budworm control program. Bull. Ent. Soc. Am. 33: 86-90.

Kinghorn, J.M., R.A. Fisher, T.A. Angus and A.M. Heimpel. 1961. Aerial spray trials against the black headed budworm in British Columbia. Can. Dep. For., Bimonthly Prog. Rep. 17: $3-4$.

Krieg, A. and G.A. Langenbruch. 1981. Susceptibility of arthropod species to Bacillus thuringiensis. pp. 837-896 In Burges, H.D. (Ed.). Microbial control of Pests and Plant Diseases 1970-1980. Academic Press, London.

Kettela, E.G. 1983. Operational use of Bt in New Brunswick. Part 2. Efficacy. pp. 46-53. In Carrow, J.R. (Ed.). Bt and the spruce budworm-1983. NB Dep. Nat. Resour. Fredericton, N.B.

Kettela, E.G. 1985. Review of foliage protection spray operations against the spruce budworm with Bacillus thuringiensis kurstaki from 1980 to 1983 in Nova Scotia and New Brunswick, Canada. pp. 19-22 In Grimble, D.C. and F.B. Lewis (Eds.). Proc. Symp.: Microbial Control of Spruce Budworms and Gypsy Moths. USDA For. Serv. GTR-NE-100.

Lambert, M. 1987. Quantification of spray deposits in experimental and operational aerial spraying operations. pp. 125-129 In Green, G.W. (Ed.). Proc. Symp. on the aerial application of pesticides in forestry. Assoc. Comm. on Agric. and For. Aviation. NRC Ottawa, AFA-TN-18, NRC No. 29197.

Lewis, F.B., G.S. Walton, J.B. Dimond, O.N. Morris, B. Parker and R.C. Reardon. 1984. Aerial application of Bt against spruce budworm: $1982 \mathrm{Bt}$ cooperative field testscombined summary. J. Econ. Ent. 77: 999-1003.

Luthy, P. 1986. Genetics and aspects of genetic manipulation of Bacillus thuringiensis. p. 97-110 In: Krieg, A. and A.M. Huger (Eds.). Symposium in memorium Dr. Enrst Berliner anlasslich des 75. Jahrestage der Erstbeschreibung von Bacillus thuringiensis. Mitt. Aus der Biologischen Bundesanstalt fur Land- and Forstwirtschaft. Heft 223, Berlin-Dahlem.
Martin, P.A.W. and R.S. Travers. 1989. Worldwide abundance and distribution of Bacillus thuringiensis isolates. Appl. Env. Microbiol. 55: 2437-2442.

Morris, O.N. 1976. A two year study of the efficacy of B.t.chitinase combinations in spruce budworm control. Can. Ent. 108: 225-233.

Morris, O.N. 1977. Long term study of the effectiveness of aerial application of Bacillus thuringiensis-acephate combinations against the spruce budworm, Choristoneura fumiferana (Lepidoptera: Tortricidae). Can. Ent. 109: 1239-1248.

Morris, O.N. 1980. Report of the 1979 CANUSA cooperative Bacillus thuringiensis spray trials. FPM-X-40, Can. For. Serv., Sault Ste. Marie, Ont.

Morris, O.N. 1981. Report of the 1980 cooperative Bacillus thuringiensis spray trials. FPM-X-48, Can. For. Serv., Sault Ste. Marie, Ont.

Morris, O.N. 1982a. Report of the 1981 cooperative Bacillus thuringiensis spray trials. FPM-X-58, Can. For. Serv., Sault Ste. Marie, Ont.

Morris, O.N. 1982b. Bacteria as pesticides: forest applications. pp. 239-287. In Kurstak, E. (Ed.). Microbial and Viral Pesticides. Marcel Dekker, New York.

Morris, O.N. 1984. Field response of the spruce budworm, Choristoneura fumiferana (Lepidoptera: Tortricidae) to dosage and volume application rates of commercial Bacillus thuringiensis. Can. Ent. 116: 983-990.

Morris, O.N. and J.A. Armstrong. 1974. Aerial application of Bacillus thuringiensis-Orthene combinations against the spruce budworm. CC-X-71, Can. For. Ser., Ottawa, Ont.

Morris, O.N., T.A. Angus and W.A. Smirnoff. 1975. Field trials of Bacillus thuringiensis against the spruce budworm, 1960-1973. pp. 129-133 In Prebble, M.L. (Ed.). Aerial Control of Forest Insects in Canada. Dept. Environ., Ottawa, Ont.

Morris, O.N., M.J. Hildebrand and J.A. Armstrong. 1980. Preliminary field studies on the use of additives to improve deposition rate and efficacy of commercial formulations of Bacillus thuringiensis applied against the spruce budworm. FPM-X-32, Can. For. Serv, Sault Ste. Marie, Ont.

Morris, O.N. and A. Moore. 1983. Relative potencies of 50 isolates of Bacillus thuringiensis for larvae of the spruce budworm, Choristoneura fumiferana (Lepidoptera: Tortricidae). Can. Ent. 115: 815-822.

Morris, O.N., J.B. Dimond and F.B. Lewis. 1984. Guidelines for operational use of Bacillus thuringiensis against the spruce budworm. USDA For. Serv., Agriculture Handbook No. 621, Washington, D.C.

Mott, D.G., T.A. Angus, A.M. Heimpel and R.A. Fisher. 1961. Aerial application of Thuricide against the spruce budworm in New Brunswick. Can. Dep. For., Bi-monthly Prog. Rep. 17: 2.

Nigam, P.C. 1987. Dose transfer and spruce budworm behaviour during operational application of fenitrothion. pp. 281-184 In Green, G.W. (Ed.).

Percy, J. and P.G. Fast. 1983. Bacillus thuringiensis crystal toxin: ultrastructural studies of its effect on silkworm midgut cells. J. Invert. Pathol. 41: 86-98.

Picot, J.J.C., X. Bontemps and D.D. Kristmanson. 1985. Measuring spray atomizer droplet spectrum down to $0.5 \mu \mathrm{m}$ size. Trans. ASAE 28: 1367-1370.

Picot, J.J.C., D.D. Kristmanson and N. Basak-Brown. 1986. Canopy deposit and off-target drift in forestry aerial spraying: the effects of operational parameters. Trans. ASAE 29: 90-96.

Pimentel, D., M.S. Hunter, J.A. LaGro and R.A. Efroymson. 1989. Benefits and risks of genetic engineering in agriculture. BioScience 39: 606-614.

Pozsgay, M., P. Fast, H. Kaplan and P.R. Carey. 1987. The effect of sunlight on the protein crystals from Bacillus thuringiensis varieties kurstaki HD-1 and NRD-12: a Raman spectroscopic study. J. Inv. Path. 50: 246-253. 
Retnakaran, A., H. Lauzon and P.G. Fast. 1983. Bacillus thuringiensis induced anorexia in the spruce budworm, Choristoneura fumiferana. Ent. exp. et appl. 34: 233-239.

Smirnoff, W.A., J.J. Fettes and R. Desaulniers. 1973. Arial spraying of a Bacillus thuringiensis-chitinase formulation for control of the spruce budworm. Can. Ent. 105: 1535-1544.

Smirnoff, W.A. 1974. Three years of aerial field experiments with Bacillus thuringiensis plus chitinase formulation against the spruce budworm. J. Invert. Pathol. 24: 344-348.

Smirnoff, W.A. 1980. Deposit assessment of Bacillus thuringiensis formulations applied from an aircraft. Can. J. Microbiol. 26: 1364-1366.

Smirnoff, W.A. 1985. Field tests with highly concentrated Bacillus thuringiensis formula against spruce budworm. pp. 55-59 In Grimble, D.G and F.B. Lewis (Ed.).

Smirnoff, W.A. and O.N. Morris. 1982. Field development of Bacillus thuringiensis in eastern Canada. pp. 238-247 In Kelleher, J.S. and M.A. Hulme (Eds.). Biological Control Programmes Against Insect and Weeds in Canada 1969-1980. Commonwealth Agricultural Bureaux.

Smirnoff, W.A. and J.R. Valero. 1983. Characteristics of a highly concentrated Bacillus thuringiensis formulation against spruce budworm, Choristoneura fumiferana (Lepidoptera: Tortricidae). Can. Ent. 115: 443-444.

Travers, R.S., P.A. Martin and C.F. Reichelderfer. 1987. Selective process for efficient isolation of soil Bacillus spp. Appl. Env. Microbiol. 53: 1263-1266.

van Frankenhuyzen, K. and C.W. Nystrom. Residual toxicity of a high-potency formulation of Bacillus thuringiensis to spruce budworm (Lepidoptera: Tortricidae). J. Econ. Entom. 82: 868-872.

van Frankenhuyzen, K. and P.G. Fast. Susceptibility of three coniferophagous Choristoneura species (Lepidoptera: Tortricidae) to Bacillus thuringiensis var. kurstaki. J. Econ. Ent. 82: 193-196.

van Frankenhuyzen, K., C. Howard, J. Churcher, G. Howse and D. Lawrence. 1989. Deposition and efficacy of Dipel $8 \mathrm{AF}$ applied diluted and undiluted against the gypsy moth in southeastern Ontario. For. Can., For. Pest Manage. Inst. Inf. Rep. FPM-X-84, Sault St. Marie.

van Frankenhuyzen, K. 1990. Effect of temperature and exposure time on toxicity of Bacillus thuringiensis spray deposits to spruce budworm, Choristoneura fumiferana (Lepidoptera: Tortricidae). Can. Ent. 122: 69-75.

van Vliet, M.W. and J.J.C. Picot. 1987. Drop spectrum characterization for the Micronair AU4000 aerial spray atomizer. Atom. Spray Technol. 3: 123-134.

West, R.J., A.C. Raske, A. Retnakaran and K.P. Lim. 1987. Efficacy of various Bacillus thuringiensis var. kurstaki formulations and dosages in the field against the hemlock looper, Lambdina fiscellaria fiscellaria (Guen) (Lepidopetra: Geometridae) in Newfoundland. Can. Ent. 119: 449-458.

West, R.J., A.G. Raske and A. Sundaram. 1989. Efficacy of oil-based formulations of Bacillus thuringiensis var. kurstaki against hemlock looper, Lambdina fiscellaria fiscellaria (Guen.) (Lepidoptera: Geometridae). Can. Ent. 121: 55-63.

Whiteley, H.R. and H.E. Schnepf. 1986. The moleculecular of parasporal crystal body formation in Bacillus thuringiensis. Ann. Rev. Micobiol. 40: 549-576.

Wiesner, C.J. and E.G. Kettela. 1987. 1986 Dipel deposit-efficacy studies and bioassay validation. New Brunswick Research and Productivity Council report C/86/110.

Wilcox, D.R., A.G. Shivakumar and B.E. Melin. 1986. Genetic engineering of bioinsecticides. p. 395-413 In: Inouye, M. and R. Sarma (Eds.). Protein Engineering: Applications in Science, Medicine, and Industry. Academic Press, Inc.

Yates, W.E. and R.E. Cowden. 1986. Drop size spectra for Beecomist, Micronair, and an 8006 flat fan nozzle with Dipel $8 \mathrm{~L}$ and Thuricide 48LV. FPM 86-4, USDA For. Serv., For. Pest Manage., Davis, Calif.

Zehnder, G.W. and W.D. Gelernter. 1989. Acitivity of the MOne formulation of a new strain of Bacillus thuringiensis against the colorado potato beetle (Coleoptera: Chrysomelidae): relationship between susceptibility and insect life stage. J. Econ. Entomol. 82: 756-761

\section{UNIVERSITY OF NEW BRUNSWICK}

\section{Faculty of Forestry}

The Department of Forest Resources invites applications for a tenure track position in Forest Mensuration/Biometry at the Assistant Professor level beginning January 1,1991 . A PhD or equivalent experience is required.

The appointee will teach undergraduate and graduate courses, supervise graduate students, and mount a strong research program. Applicants should have research interests in growth and yield.

In accordance with Canadian immigration requirements, this advertisement is directed to Canadian citizens and permanent residents. The University of New Brunswick is committed to the principle of employment equity.

Applications, including a curriculum vitae and names of three referees, should be submitted to:

$$
\begin{gathered}
\text { Dr. G.L. Baskerville } \\
\text { Dean, Faculty of Forestry } \\
\text { University of New Brunswick } \\
\text { Bag Service \#44555 } \\
\text { Fredericton, NB } \\
\text { Canada E3B 6C2 }
\end{gathered}
$$

